Piotr Zamojski

Liverpool Hope University

\title{
Theory and the way we relate to the world. On the educational dimension of insight
}

Following the origin of the concept of theory, and the Greek word $\theta \varepsilon \omega p i a$, Heidegger observes: "[...] theōrein is theanhoran, to look attentively on the outward appearance wherein what presents becomes visible and, through such sight - seeing - to linger with it" (Heidegger 1977: 163)

What I aim to indicate with this paper is the educational dimension of theory. This, however, is possible not because every theory can be a subject matter of educational processes, or because it can influence the course of these processes, but because a theory of any kind entails a particular way of relating humans to the world.

Theory is a way one looks and sees, a way one is attentive to and beholds what there is, and, precisely as Heidegger claimed, through such an insight one relates to what is seen. This means, however, that using a theory, theorizing, working with theory, exploring it, assuming a theoretical standpoint... etc., all this, is more than just dealing with a particular corpus of texts, concepts and intellectual devices. What is often forgotten about bios theōrettikos is that - apart from the fact that it is a common attitude for humans - it also means shaping oneself and entering a particular relation with the world in accordance with the line of the insight. The "[...] outward look, the aspect, in which something shows itself, that outward appearance in which it offers itself" (Heidegger 1977: 163) while granting us with a part of the world, relates us to it in a particular way.

If education is all about establishing one's relation to the world (cf. Biesta 2010; Masschelein 2011; Vlieghe 2016), this is essentially the educational dimension of theory. In the following argument, I will make an attempt at describing three theoretical standpoints - two of which can be considered as the most influential for the social sciences in the $20^{\text {th }}$ century - emphasizing their educational dimension in the meaning indicated above. I will conclude with some more general remarks on the educational dimension of theory - with regard to educational theory especially. 


\section{Technology - ruling and exploiting the world}

Science, as early as Francis Bacon's time, has aimed at gaining knowledge, which gives humans power over nature. Aspiring to such a task, science should be able to grasp the causal relations governing the world of nature (its laws) resembling the relationship between the means and the goals of human actions. Hence, modern science is mostly concerned with producing a theory that would give people the power to act and rule over nature. Such a way of relating to the world is expressed just at the very beginning of the idea of modern science, i.e. in the third aphorism of Novum Organum: "Human knowledge and human power come to the same thing, because ignorance of cause frustrates effect. For Nature is conquered only by obedience; and that which in thought is a cause, is like a rule in practice" (Bacon 2000 [1620]: 33).

According to Max Horkheimer and Theodor W. Adorno, thanks to the astonishing success of the scientific method (cf. the significance of Newcomen's/Watt's invention for industrialisation), the understanding of theory in late modernity was predominantly technological, and became the main way in which human beings addressed not only nature, but also each other:

Not only is domination paid for with the estrangement of human beings from the dominated object, but the relationships of human beings, including the relationship of individuals to themselves, have themselves been bewitched by the objectification of the mind (Horkheimer, Adorno 1973: 21).

This "objectification of the mind" means the domination of the technical way of addressing the world by humans; the domination of one form of thinking, one rationality, and hence the domination of a certain, coherent way of perceiving reality, and thinking and acting within that reality. In other words, the given shape of a theory assumes its proper vision of the subject, who is not just the theory's founder, but mostly its user, as theory becomes the matrix for its own cognitive, reflective and practical way of addressing the world. In this view the world is a resource to be used by humans. Within this standpoint using resources is understood in terms ofthe knowledgeable manipulation of the laws of nature for the sake of a particular goal. The crucial point here is that technology is not interested in the nature of such a goal, but purely in establishing effective means. The very aim of technology is to develop the knowledge revealing such means, not to reflect on the possible goals as worthy to be desired or not.

In other words, the regularities of nature found in the process of scientific research transform the world into a set of means used in the realisation of particular goals. It is a world seen through the eyes of a purely formal subject (Zamojski 2010) constructed by an instrumental reason which, minimizing all thinking to calcula- 
tion (Horkheimer, Adorno 1973: 18-19; v. also Heidegger 1977), reduces all ethical issues into technical problems that are to be solved.

The formal subject, which is focused on the effective execution of given tasks, is therefore unable to question its own actions and their normative sense. The only questions which are worthy of being posed for instrumental reason concern the means of achieving goals, i.e. the procedures of effective actions.

This focus on the effectiveness of action and the inability of normative reflection about its (ethical) sense causes therefore the danger of a readiness to participate in evil. In this sense, according to Horkheimer and Adorno, one deals with the "mysterious willingness of the technologically educated masses to fall under the spell of any despotism" (Horkheimer, Adorno 1973: XVI). An efficient executor, devoid of normative reflection, is unable to define the goals of his or her actions, nor to pose questions whether the goals-tasks set upon her or him are right. The heteronomous formal subject thus disregards the contents of its actions which, from the perspective of the logic of effectiveness, become optional. Max Horkheimer and Theodor W. Adorno point out that:

The technical process, to which the subject has been reified after the eradication of that process form consciousness, is as free from the ambiguous meanings of mythical thought as from meaning altogether, since reason itself [...] serves as a universal tool for the fabrication of all other tools, rigidly purpose-directed [...]. Reason's old ambition to be purely an instrument of purposes has finally been fulfilled (Horkheimer, Adorno 1973: 23).

This danger of being ready to participate in evil is additionally strengthened in the modern world of common specialization, in which the sense of all composed actions becomes increasingly cognitively intangible for subjects which deal with specialized, fragmentary actions. This means that our private responsibility as the executors of these tasks becomes increasingly vague. This is why, as pointed out by Hannah Arendt (2006), the formal subject, which focuses on effective task performance, may participate in genocide, dutifully performing banal daily chores. Therefore Auschwitz was found to be the radical expression of instrumental rationality as the thoughtlessness of a purely descriptive, non-normative, technical consciousness, devoted to the principles of effectivity, productivity and performativity - that is, consciousness focused on safeguarding the means to any kind of goals, being externally imposed as valid.

However, "a new categorical imperative" which arose from such consideration, and that simultaneously was supposed to stand for the one and only educational aim ever since ("[...] to arrange [...] thoughts and actions so that Auschwitz will not repeat itself, so that nothing similar will happen") (Adorno 2004: 365) - was not tantamount to the abandoning of reason at all. 


\section{Critique - oppression and emancipation}

This is because the properties of reason have not been exhausted in the search for the means to an end. A way of thinking about theory, aimed at overcoming instrumental rationality as the dominant form of reason, was developed thanks to the launching of reason's negative, critical power. Critical rationality as a movement of negation that never stops and is not transformed into any kind of positivity (Adorno 2004, e.g.: 3-10), brings to life a new vision of the subject as an alert, distrustful and suspicious critic of the surrounding reality. Critical theory equips humans with tools which enable them to identify the strategy of forces falsifying the consciousness of the vast social masses aiming at sustaining the facade of democracy and social injustice.

The proposition of critical reason - which later on wasthefoundation for the emergence of critical pedagogy - assumed that consequent questioning, an investigation aimed at unmasking the false appearance of things and de-naturalisation of the social status quo, will re-establish the ethical dimension of matters of concern, and will make us unable to be blindly subordinated to some external power and therefore reduced to an intelligent and creative tool ( $c f$. Horkheimer 2004). Thanks to human's power of critique one should be able to pose normative questions which extensively go beyond narrow, instrumental rationality, and its desire for effectivity. Instead of simply asking about 'how to achieve this, or that goal efficiently?' the critical subject is questioning what is set out to be done by asking 'is that right?' / 'should this be done?'. This shift in attitude is supposed to reclaim the ethical sense of the human relation to the world, and in that way our critique is supposed to make us unable to participate in evil.

There are naturally different kinds of theorising about critical reason (even in the Frankfurt school itself) as there are different frameworks of critical pedagogy, but critique - as the move of critical consciousness towards seeing things as they are in their complexity, and political, ideological, and therefore ethical entanglement is always linked with the hope for a just and un-reified society, for the liberation of the enslaved, for the empowerment of the marginalised (cf. Freire 2000; 2005; Mollenhauer 1968).

The apology of critique - which critical pedagogy in its diverse forms radically assumes - defines the power of critique through the symmetry of knowing, perceiving and doing. If one knows what the world is about, if one decodes and perceives the dangers of injustice, slavery, and any other kind of evil - one will do everything to emancipate / to empower / to change the oppressive order.

But what is the educational sense of such a theoretical standpoint? What is the way this theory relates us to the world? Who is 'us' in this standpoint? In what way does the critical paradigm shape its 'users'?

The critics of the critical pedagogy have argued that it operates within the instrumental rationality itself ( $c f$. Ellsworth 1989; Gur-Ze'ev 1998). Critical pedagogy 
has a very strict normative structure, which is imposed as the onlylegitimate one, and so it has the potential to reduce itself and become an orthodoxy, transforming the critical act into a repeatable scheme inducing predictable outcomes ( $c f$. Maddock 1999).

Therefore, it can conceive of education in terms of the process of the production of $a$ priori designed effects; a process that should be efficient in making critical citizens, in establishing strong democracy, empowering the poor... etc. In other words, critical pedagogy has the potential to be the expression of instrumental rationality which it tried to overcome in the first place (Masschelein 2004).

Jacques Rancière - while referring to the post-Bourdieu educational reforms in France - noticed that education driven by critical knowledge on social order defines pupils / students as enslaved, as in need of empowerment, in the need to be emancipated, and by constantly treating them like that, makes this enslavement their conditio humana (Rancière 2004). Hence, such critically based education delays their freedom and autonomy ad infinitum and reproduces the social order it claimed to transform (Rancière 1991).

What Peter Sloterdijk (1987) adds is that this unhappy consciousness of a slave who is being enlightened doesnot end with emancipation. Instead of this, it transforms into an enlightened false consciousness - and ends up with cynicism. Therefore there is no link between critical knowledge, the ability to decode and perceive the ethical dangers, and the human action itself. We can know of slavery, injustice, discrimination, racism, and all other kinds of evil, as well as we can be aware of our own entanglement in their apparatus, and still do nothing to change it.

What is most important here is that Sloterdijk argues that cynicism is not simply a potential of the human psyche. Rather, it is the effect of critique - critique which is radical, unrestrained, consequent, and irresistible. Sloterdijk argues that the more radical our critique becomes, the less hope it leaves - until it leaves no way out (Sloterdijk 1987, e.g.: 5-6). We have to stick to the status quo, because any changes seem to be impossible: there is no chance for a flat field in Bourdieu's view; there is no chance for powerless relations in Foucault's view etc.

In addition, there is something essentially anti-educational, i.e. destructive in the critical attitude. Bruno Latour (2004) observes:

Wars. So many wars. Wars outside and wars inside. Cultural wars, science wars, and wars against terrorism. Wars against poverty and wars against the poor. Wars against ignorance and wars out of ignorance. My question is simple: Should we be at war, too, we, the scholars, the intellectuals? Is it really our duty to add fresh ruins to fields of ruins? Is it really the task of the humanities to add deconstruction to destruction? More iconoclasm to iconoclasm? What has become of the critical spirit? Has it run out of steam? (Latour 2004: 225)

Emerging as the response to the ashes of the Holocaust, critical reason - when fulfilled - seems to be the enemy of the world. Within the critical rationality, the world is an oppressive force subjugating individuals. We ought to counter such an 
oppression in order to emancipate, and not to just pass on this world to the new generation. ${ }^{1}$ At least from the times of the previously mentioned Francis Bacon countering the world's oppression on humans means conquering the world itself, gaining control over it, over ourselves and our lives. In this way we are back into the mechanism of the dialectic of enlightenment - the critical theory which arose out of a response to the dangers of technology repeats its initial desire to conquer the world. The intentions behind it are different, and so are the intellectual devices at use and the aims to achieve. These are different theoretical standpoints, and to a certain extent different ways of relating to the world, but in both cases the subject is to expand on, and appropriate the world.

\section{Responsibility - care and attention}

The third way of theorising that I would like to analyse regarding the educational dimension of theory has emerged in the second half of the 20th century through the conceptualisation of responsibility - as conceived by Georg Picht and Hans Jonas.

The philosophy of responsibility they have independently created reflects explicitly on the quality of the relation between humans and the world, and in that sense seems to be essentially educational. This world is for both - Picht and Jonas - essentially weak. After Auschwitz and Hiroshima we cannot claim any longer that humans are subjugated and oppressed by the world, at least in general terms. On the contrary, they have now the power to destroy it. By virtue of technological development humans have so radically increased the power of their actions that indeed - now it is they from whom the threat arises (Jonas 1984: 136-142; Picht 1998: 198-199).

The weak world needs our care. It is a good entrusted to us, a good for the existence of which we are responsible. This responsibility has an ontological character. Humanity is responsible, and therefore can behave in a responsible or irresponsible manner (Jonas 1984: 90-95). Such an ontologization of responsibility (Filek 1996) links with the supplementing of its formal (negative) reference - i.e. the responsibility of a doer (responsibility for done deeds) and related notions of causality and authorship, by a substantive (positive) reference of responsibility for what is to be done (Picht 1998: 193).

As Picht observes, humanity is responsible for everything that happens in the range of its power, in the domain of the possible (Picht 1998: 193-194, 198). Jonas (1984) adds that we are responsible for what is to be done in the affairs that matter (Jonas 1984: 92-93).

${ }^{1}$ Indeed, there seems to be an increasingly recognized significance for the Arendtian concept of education as an alternative for critical pedagogy; $c f$. Vlieghe 2016; Hodgson, Vlieghe, Zamojski 2017; Arendt 1968. 
The "what for" lies outside me, but in the effective range of my power, in need of or threatened by it. It confronts this power of mine with its right-to-be [...]. The matter becomes mine because the power is mine and has a causative relation to just this matter. The dependent in its immanent right becomes commanding, the power in its transitive causality becomes committed, and committed in the double sense of being objectively responsible for what is thus entrusted to it, and affectively engaged (Jonas 1984: 92).

The calling of humanity is therefore taking responsibility. In order to cope with such a call one needs to sensitize oneself to good; good from the world that may be lost, that is endangered, weak, but simultaneously lies in the range of our power; good about which we can do something (Picht 1998: 202). The recognition of this good - as Picht and Jonas suggest - is always contextual, and requires to judge every time in a particular situation about what is necessary to preserve this good, to what the good calls upon us to do (Picht 1998: 194, 199; Jonas 1984: 93-98). A human being is not therefore focused on themselves, but has to make space in themselves for this matter, retreat, give way to. Picht (1998) expresses this by saying:

"service" requires that the bearers of responsibility forget themselves [...]. Responsibility implies the relinquishment of the self insofar as responsible people are absorbed by the task set before them, dedicating themselves to caring for those people and things entrusted to their keeping (Picht 1998: 200).

Responsibility assumes therefore an intimate relation with the world that induces actions made for the sake of the world - not against it, but because of the good it entails. This good needs our attention. We need to make room in ourselves in order to let it be, help it survive, preserve it, pass it on to the next generation. No external instance is necessary. No ideal future needs to be designed. We have to simply recognize the matter, the good that lies in the range of our power, a thing worth preserving that we can do something about. This standing back, withdrawal from the self, requires an effort. One needs to do a lot to stand back, and let it be.

What is needed to be done is to fall in love with the world, to become passionate about its particular dimension, a part, a subject matter. As quoted above from Picht "responsible people are absorbed by the things / other people entrusted to their keeping". Responsibility is therefore linked with attention in two ways. Firstly, it is about being attentive to the good in the world that needs our care, and "demands" that care from those who can do anything for the sake of that good in the range of their powers. Secondly it is about being completely absorbed by that good and the task of its preservation, i.e. about studying and teaching - turning that good into a subject matter.

\section{Concluding remarks}

I have made an attempt to indicate the ways in which three distinct theoretical standpoints frame human relations with the world. 
Technology views the world in terms of a resource. The laws of nature need to be discovered in order to be used for the purposes of humans. Thus the world is something to be appropriated, and not, for example, inhabited or cared for and passed on.

Critique perceives the world in terms of an unjust and oppressive structure that must be overcome in order to liberate oppressed humans. The world seems to be a blind force to be struggled with, a set of arbitrary conditions privileging some and marginalising others.

Both technology and critical theory - although ideologically in opposition share a view of humans being at war with the world. The relation between these two sides is essentially a power relation, and it is conquest which is at its heart.

In the case of responsibility, the human-world relation assumes the weakness of the world and the limited power of humans. However, it is exactly within these limited powers that a human being is responsible for the existence of good inherent to the world itself. There are things worth being cared for and passed on to the next generations. We should be attentive to them, devote ourselves to them, be in love with the world.

The line of the exercise made within this paper has its own importance which I have tried to defend elsewhere (Zamojski 2014). Here, by such an exercise I intended to indicate the existence of an educational dimension of theory as such. This might be taken into consideration when attempts are made to re-invent educational theory.

What could be called theory's educational dimension doesnot concern the expected outcomes of an action informed by a particular theory, but instead of that, it is expressed in the way that a theory relates humans to the world. It is exactly the kind of such a relation that - regardless of the results of our actions (intended or not, expected or not) - is shaping ourselves and our world when we act in line or when we are inspired by a particular theory. Acting in line with a theory, we can end up with diverse results - also opposite to our intentions - but in any of such cases we are entering a particular relation with the world (with ourselves, other people, things and objects, meanings etc.). This could be regarded as particularly significant in the case of educational theories themselves, but it seems that still we do not take this circumstance into account enough.

\section{Literature}

Adorno T.W., 2004 [1966], Negative Dialectic, transl. E.B. Ashton, New York-London: Continuum.

Arendt H., 1968, The Crisis of Education, [in:] eadem, Between Past and Future, New York: Penguin.

Arendt H., 2006, Eichmann in Jerusalem: a Report on the Banality of Evil, New York: Penguin Books.

Bacon F., 2000 [1620], The New Organon, transl. by L. Jardine, M. Silverthorne, Cambridge: Cambridge University Press. 
Biesta G.J.J., 2010, Education, Weakness, Existence, the Soul and Truth: Five Reminders about the Basic Questions of Education, "Ars Educandi" Vol. 7, pp. 55-69.

Ellsworth E., 1989, Why Doesn't This Feel Empowering? Working Through The Repressive Myths of Critical Pedagogy, "Harvard Educational Review" Vol. 59 (3), pp. 297-324.

Filek J., 1996, Ontologizacja odpowiedzialności: analityczne i historyczne wprowadzenie $w$ problematyke [Ontologization of Responsibility: Analytical and Historical Introduction to the Problematics], Kraków: Wydawnictwo Baran i Suszczyński.

Freire P., 2000, Pedagogy of the Oppressed, transl. by M. Bergman Ramos, New York-London: Continuum.

Freire P., 2005, Education for Critical Consciousness, New York-London: Continuum.

Gur-Ze'ev I., 1998, Toward a Non-repressive Critical Pedagogy, "Educational Theory" Vol. 48 (4), pp. 463-486.

Heidegger M., 1977, Science and Reflection [in:] idem, The Question Concerning Technology and Other Essays, transl. by W. Lovitt, New York - London: Garland Pub.

Hodgson N., Vlieghe J., Zamojski P., 2016, Manifesto for a Post-Critical Pedagogy, New York: Punctum Press.

Horkheimer, M., 2004, Eclipse of Reason, London - New York: Continuum

Horkhemer M., Adorno T.W., 1973 [1944], Dialectic of Enlightenment, trans. J. Cumming, New York: Continuum.

Jonas H., 1984, The Imperative of Responsibility: in Search of an Ethics for the Technological Age, Chicago: The University of Chicago Press.

Latour B., 2004, Why Has Critique Run out of Steam? From Matters of Fact to Matters of Concern, "Critical Inquiry" Vol. 30 (4).

Maddock T., 1999, The Nature and Limits of Critical Theory in Education, "Educational Philosophy and Theory" Vol. 31 (1), pp. 43-61.

Masschelein J., 2004, How to Conceive of Critical Educational Theory Today?"Journal of Philosophy of Education" Vol. 38 (3), pp. 351-367.

Masschelein J., 2011, Experimentum Scholae: The World once More... But Not (Yet) Finished, "Studies in Philosophy and Education" Vol. 30, pp. 529-535.

Mollenhauer, K., 1968, Erziehung und Emanzipation. Polemische Skizzen. München: Juventa.

Picht G., 1998, The Concept of Responsibility, transl. by W. Davis, "Religion” vol. 28.

Rancière J., 1991, The Ignorant Schoolmaster. Five Lessons in Intellectual Emancipation, transl. by K. Ross, Stanford: Stanford University Press.

Rancière J., 2004, The Philosopher and His Poor, transl. by J. Drury, C. Oster, A. Parker, Durham-London: Duke University Press.

Sloterdijk P., 1987, Critique of Cynical Reason, transl. by M. Eldred, Minneapolis: University of Minnesota Press.

Vlieghe J., 2016, Edukacja w warunkach szkolnych. Ku pedagogice skupionej na rzeczy [Education in School Conditions. Towards Thing-Centres Pedagogy], transl. by P. Zamojski, "Studia i Badania Naukowe. Pedagogika" Vol. 10, No. 1, pp. 15-33.

Zamojski P., 2010, Pytanie o cel kształcenia - zaproszenie do debaty [The Question of the Purpose of Education - an Invitation to Debate], Gdańsk: Wydawnictwo Uniwersytetu Gdańskiego.

Zamojski P., 2014, Od demaskacji ku budowaniu. Po-krytyczna perspektywa badań pedagogicznych [From Unmasking to Building. Post-critical Perspective of Pedagogical Research], “Teraźniejszość - Człowiek - Edukacja” Vol. 67 (3), pp. 7-22. 


\section{Summary \\ Theory and the Way We Relate to the World. \\ On the Educational Dimension of Insight}

This paper investigates the educational dimension of theory, that is, the way theory forms or catalyses human's relation to the world. This is analysed through the examples of three theoretical standpoints: technology, critique and the philosophy of responsibility. The first two have played their major part in contemporary thought, while the third seems to play a crucial role in currently emerging theories of education. However, the exercise presented in this paper does not aim at apprising one of these standpoints over the others. Rather, it indicates the educational work of theory beyond its application and function.

\section{Keywords}

educational dimension of theory, educational theory, technology, critique, the philosophy of responsibility, Jonas, Picht, Heidegger

Proofreading: Anna Moroz-Darska

Tłumaczenie sfinansowano ze środków Ministerstwa Nauki i Szkolnictwa Wyższego na podstawie umowy nr 661/P-DUN/2018 z dnia 13 lipca 2018 roku w ramach realizacji zadania 1 - stworzenie anglojęzycznych wersji wydawanych publikacji w 2019 roku.

The translation was financed with funds made available by the Ministry of Finance and Higher Education under contract No. 661/P-DUN/2018 of 13 July 2018 as a part of the execution of task 1 : the creation of English-language versions of the issued publications in 2019. 